Short paper

\title{
Record of Iridescent shark catfish Pangasianodon hypophthalmus Sauvage, 1878 (Siluriformes: Pangasiidae) from Madampa-Lake in Southwest Sri Lanka
}

\author{
Hareschandra Bandula Jayaneththi \\ Young Zoologists' Association of Sri Lanka, National Zoological Gardens, Sri Lanka \\ Nagenahiru Environmental Education Centre, Ambalangoda, Sri Lanka \\ *Correspondence: bjayaneththi@gmail.com \\ Received: $08^{\text {th }}$ November 2015, Revised: $14^{\text {th }}$ December 2015, Accepted: $21^{\text {st }}$ December 2015
}

\begin{abstract}
An exotic catfish was recorded at Madampa Lake in Southwest coastal zone of Sri Lanka during an ichthyofaunal survey carried out from $1^{\text {st }}$ of April 2009 to $20^{\text {th }}$ August 2010. The species is identified as Pangasianodon hypophthalmus, which has been described as a potentially problematic species on native fishes in some neighbouring countries of the region. This species naturally occurs in the Mekong River in South-East Asia. The observation of $P$. hypophthalmus is a novel record in wild habitats of Sri Lanka, where its introduction is probably an accidental release from the ornamental fish trade, but no substantial information is detected as a proof of invasion or a naturalisation of the current population.
\end{abstract}

Keywords. Exotic, introduced species, invasive species, naturalisation.

\section{Introduction}

Impact of introduced populations of species can be varied with their behavioural ecology. While many species fail to survive in new habitat beyond their previous geographical range populations, some species establish very well, some are naturalising, and some show invasion in new habitats by many different ways and levels. For an example, introduction of the Nile perch Lates niloticus Linnaeus, 1758 resulted in the extinction of more than 200 native fish species in Lake Victoria (Lowe et al 2000).

Exotic ichthyofauna in Sri Lanka has a history of at least 125 years, with the introduction of Rainbow trout Oncorhynchus mykiss Walbaum, 1792 
released in to hill streams of the island by the 'Ceylon Fishing Club' in 1889 to promote sport fishery (De Silva et al. 2015). Since then, many species of exotic fish have been imported and released into natural habitats and irrigation networks in the island for purposes such as sport fishery, mosquito control, aquaculture, and ornamental fish trade (Bambaradeniya 2000, 2002).

There are almost 30 exotic fish species recorded from the natural ecosystems and man-made irrigation systems in Sri Lanka over the last few decades (Pethiyagoda 1991, 2006; Bambaradeniya 1999, 2000, 2002; Silva and Kurukulasuriya 2010; Marambe et al 2011; De Silva et al 2015). It has been predicted that the potentially serious damage to the native populations of aquatic life by alien invasive species is only second to the impact caused by mankind (Pethiyagoda 2006). This short communication describes novel records of Pangasianodon hypophthalmus from Sri Lankan natural habitats as an introduced species, supplemented with a review of published records on the ecology, biology, and distribution of this species.

\section{Iridescent Shark Pangasianodon hypophthalmus from Madampa Lake}

Madampa-Lake (Madampa) is a coastal, brackish water lagoon surrounded with rich mangrove vegetation (Figure 1). It is a sanctuary located in the Southwest coast of Sri Lanka, between latitudes $6^{0} 14^{\prime} \mathrm{N}-6^{0} 13^{\prime} \mathrm{N}$ and longitudes $80^{\circ} 03^{\prime}$ E- $80^{\circ} 05^{\prime}$ E (Google Earth 2015), under the jurisdiction of the Southern Provincial council in Galle District. The main city near to the lagoon is Ambalangoda (6 $\left.6^{\circ} 13^{\prime} 30^{\prime \prime} \mathrm{N} 80^{\circ} 3^{\prime} 24^{\prime \prime} \mathrm{E}\right)$.

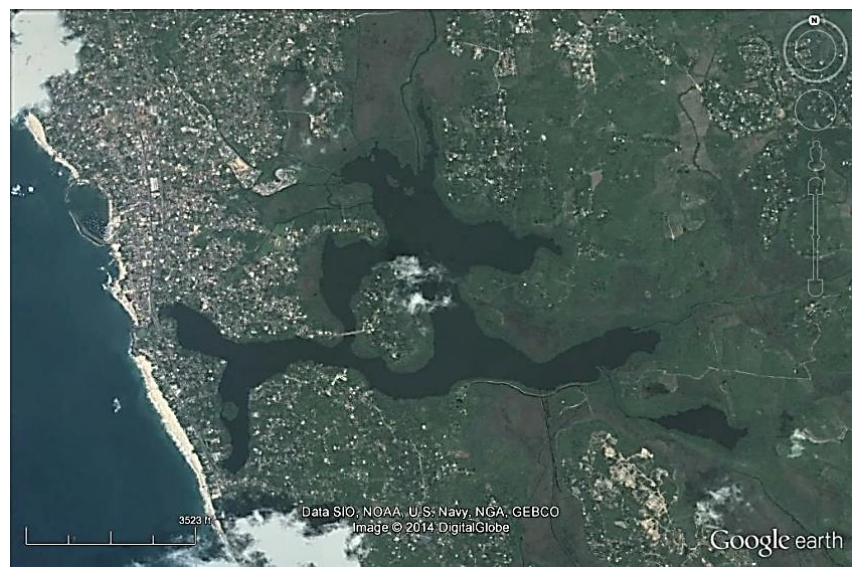

Fig. 1. Aerial view of Madampa Lake and surrounding area (Source: Google Earth 2015)

The physico-chemical parameters of water documented in Madampa includes temperature between $28 \mathrm{C}^{0}-32 \mathrm{C}^{0}$, pH 6.76-8.00, and conductivity 200-7000 mv. Madampa also contains rich density of mangrove vegetation (Fig 2a, 2b) 
such as Sonneratia caseolaris Cerbera odollam, Bruguiera sexangula, and Acrostichum aureum. Strands of exotic plants such as, Annona glabra and Phragmites karka also occur around Madampa.

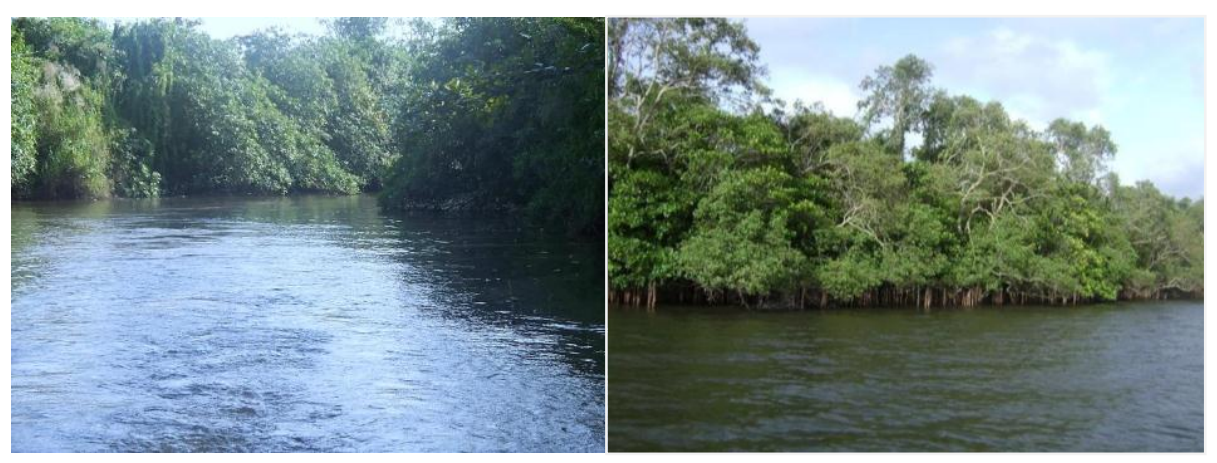

Figure 3. Madampa Lake: (a) channel connected with Madampa (left), and (b) rich mangrove vegetation in Madampa Ecosystem (right).

A survey on biodiversity in Madampa was carried out by the Nagenahiru Environmental Education Centre (NEC) from $1^{\text {st }}$ of April 2009 to $20^{\text {th }}$ August 2010. During this survey, the ichthyofauna was documented from the daily fish catches of the fishermen who engaged in fishery in this lake using gill nets; the size of the gill net was $64 \mathrm{~m} \mathrm{X} 3.8 \mathrm{~m}$ (netting mesh 2.5" X 2.5"). The fish species were identified and classified using keys provided by FAO (2010), Froese and Pauly, (2012) and Vidthayanon and Hogan (2013).

Table 1. Exotic ichthyofauna of Madampa-Lake and adjacent aquatic habitats.

\begin{tabular}{|c|c|c|c|}
\hline Family & Common name & Binomial name & Source of introduction \\
\hline Belontidae & Snake-skin Gourami & Trichogaster pectoralis & Exotic fish trade \\
\hline Cichlidae & Mossambique Tilapia & Oreochromis mossambicus & Aquaculture \\
\hline & Nile Tilapia & Oreochromis niloticus & Aquaculture \\
\hline Pangasiidae & Iridescent Shark & $\begin{array}{l}\text { Pangasianodon } \\
\text { hypophthalmus }\end{array}$ & Aquaculture \\
\hline Loricarridae & Glass Cleaner & Hypostomus plecostomus & Exotic fish trade \\
\hline Poeciliidae & Guppy & Poecilia reticulata & $\begin{array}{l}\text { Biological control of } \\
\text { mosquitoes }\end{array}$ \\
\hline
\end{tabular}

Six species of exotic fish were recorded from Madampa and its adjacent aquatic habitats (Table 1). These included specimens of the Iridescent Shark catfish Pangasianodon hypophthalmus documented for the first time in natural habitats in Sri Lanka. All three specimens of this species were caught by gill netting, which were rescued and maintained alive in an aquarium at NEC. The first specimen recorded (Standard Length $456 \mathrm{~mm}$; female) was captured on an unknown date in 2008, prior to the survey started by NEC. The 
second specimen (SL 360mm; male) was caught on February 02, 2009 and the third specimen (a sub adult, SL 238mm) captured on May 17, 2010 (Figure 3).

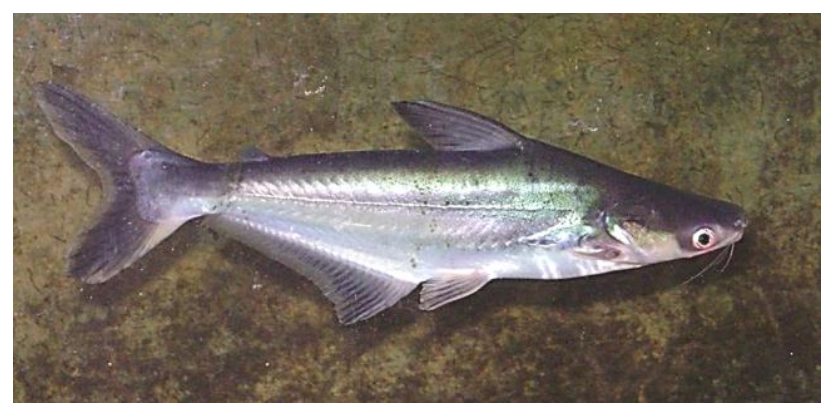

Fig. 3. Pangasianodon hypophthalmus (Siluriformes: Pangasiidae). A specimen of sub adult (SL 238mm) collected from Madampa Lake, Sri Lanka.

\section{Review of the biology, ecology and distribution of $P$. hypophthalmus}

The Iridescent shark, also called the striped catfish is a riverine fish species classified under Family Pangasiidae (Bleeker 1858). It is known to be a prolific spawner, producing large numbers of larvae, and it is a popular species in aquaculture trade due to its large body size, with a maximum standard length (SL) $1300 \mathrm{~mm}$ and $44 \mathrm{~kg}$ weight (FAO 2010; Froese and Pauly 2012; Vidthayanon \& Hogan 2013). P. hypophthalmus are benthopelagic, 'Shark' like catfishes and general colour is uniformly black or greyish black. A silvery sheen runs along the lateral body, (no scales on the skin or fins). Young $P$. hypophthalmus are more likely dark black with two silvery strips on lateral body behind the head. Fins are same colour similar to body, sometimes margined with silvery or white.

The native range of $P$. hypophthalmus is based on Mekong River and the Chaopraya River and possibly the Mekong basins in Cambodia, Lao People's Democratic Republic, Thailand and Vietnam, together with the Ayeyawady basin of Myanmar; and Introduced to several other neighbourhood countries as an aquaculture introduction, i.e. Myanmar, Malaysia, Indonesia, Bangladesh, China and India (Roberts \& Vidthayanon, 1991; FAO, 2010). Iridescent shark Inhabit large revers, marshlands and floodplains (Froese \& Pauly, 2012).

The economic value of the commercial trade of iridescent shark has resulted in fishery practices and introducing into habitats of many neighbour countries. Iridescent shark is popular in food fish trade in some European Economic Areas (EEA), in USA and in Russia (FAO, 2010) as well. However, wild populations of this species have been overharvested between 1980s and 1990 s, leading to dramatic declines of mature adults over the past three decades (Vidthayanon et al 1997). 


\section{Probability of the invasion or the naturalisation}

The introduction of $P$. hypophthalmus to Madampa is unknown. It is most likely that it has been accidentally released from an ornamental fish aquarium, as it is a common trade. During the tsunami event on December $26^{\text {th }} 2004$, some fish stocks were washed out from the industrial aquaria in the western border of Madampa, and these missing stocks reportedly included $P$. hypophthalmus. The 'Wet zone' climate and the network of aquatic systems associated with the Madampa Lake offers preferable habitat and ecological conditions similar to the native range of habitats of $P$. hypophthalmus. Madampa and its immediate boundaries are the major flood plain in the Ambalangoda area where high tide and low tide and seasonal rain floods are characteristic events around Madampa. These environmental events can cause flooding of domestic ponds and aquariums, resulting in the accidental escape of ornamental species into wild habitats.

The nature of the current 'population' of $P$. hypophthalmus in Madampa is questionable. Current observations are insufficient to state conclusively that whether the species has a breeding population or naturalised in Madampa. Iridescent shark is typically a freshwater species, preferred $\mathrm{pH}$ range: 6.5-7.5; dH range: 2-29 and temperature $22^{\circ} \mathrm{C}-26^{\circ} \mathrm{C}$ in wild (Froese and Pauly 2012; Vidthayanon and Hogan 2013). It is an omnivorous species, mostly feed on floral material, zooplankton, and insects, while adults also take fruit, some crustaceans and fish.

$P$. hypophthalmus are potamodromous, naturally, they migrate considerable distances between their upstream breeding habitats during May-July, and downstream feeding beds during September-December (Froese and Pauly 2012). This species reach average annual growth of one kilogram and up to 20 years lifespan. Many factors, including reproductive ecology, small egg size, and high fecundity suggest that the species can adapt to high mortality during early life stages (Froese and Pauly 2012; Vidthayanon, and Hogan, 2013).

After third year (around three kilogram), females reach sexual maturity in captivity, while males normally mature in their second year. Typical female $(10 \mathrm{~kg})$ can spawn over one million eggs (FAO, 2010) during lifetime. Natural populations spawn twice annually but in cages in Viet Nam have been recorded spawning a second time six to 17 weeks after the first spawning (Vidthayanon and Hogan 2013). Singh and Lakra (2012) stated on biological, environmental, disease contamination, and socio-economic issues and impact of absconded population of $P$. hypophthalmus.

Presence of males, females and juvenile/ sub adults is indicative of natural breeding, adaptation and naturalisation of introduced species. Therefore, further monitoring surveys are required on this striped shark in the Madampa 
to follow up the abundance, population structure and dynamics, and to assess the potential of it to become a breeding population.

Acknowledgements Author would like to express gratitude to Mr. L. Emmanuel (director of NEC), Ms. B. Holloway, Mr. J. Gunawardane, Mr. S. S. Chamikara, Mr. P. Samarasinghe, Mr. P. Chandrasiri, Mr. S. Emmanuel, Mr. S. Ranasinghe, and Mr. Nuwan for their valuable assistance; and especial thanking for the residences of Godahena village, Mr. Nelson and Mrs. Jayanthi provided me excellent opportunity to identify fishes on their fishing nets. Comments from two anonymous reviewers improved the text.

\section{References}

Bambaradeniya CNB. 1999. Alien invasive fauna in natural habitats and their impact on indigenous biota. In: Marambe B. (ed.). Proceedings, The first national workshop on alien invasive species in Sri Lanka, Ministry of Forestry and Environment, Sri Lanka, 45-51.

Bambaradeniya CNB. 2000. Alien invasive species in Sri Lanka. Loris, 22 (4): 3-7.

Bambaradeniya CNB. 2002. The status and implications of invasive alien species in Sri Lanka. Zoos' Print Journal 17(11): 930-935.

De Silva M, Hapuarachchi N, Jayaratne T. 2015. Sri Lankan Freshwater fishers, Wildlife Conservation Society, Galle, Sri Lanka, 391pp.

FAO. 2010. Cultured Aquatic Species Information Programme. Pangasius hypophthalmus. Cultured Aquatic Species Information Programme. Griffiths, D., Van Khanh, P., Trong, T.Q. In: FAO Fisheries and Aquaculture Department [accessed online 13 June 2015].

Froese R, Pauly D.. 2012. (FishBase) Pangasianodon hypophthalmus; http://www.fishbase.org/ (Accessed May 22, 2015)

Lowe S, Browne M, Boudjelas S, De Poorter M. 2000. 100 of the World's Worst Invasive Alien Species, A selection from the Global Invasive Species Database. Published by The Invasive Species Specialist Group (ISSG) a specialist group of the Species Survival Commission (SSC) of the World Conservation Union (IUCN), 12pp.

Marambe B, Silva P, Ranwala S, Gunawardena J, Weerakoon D, Wijesundara S, Manawadu L, Atapattu N, Kurukulasuriya M. 2011. Invasive Alien Fauna in Sri Lanka; National Lists, Impacts and Regulatory Framework, In: Island invasives: eradication and management. (Eds. Veitch, C. R.; Clout, M. N. and Towns, D. R.), IUCN, Gland, Switzerland, 445-450

Pethiyagoda R. 1991. Freshwater fishes of Sri Lanka, Wildlife Heritage Trust of Sri Lanka: Colombo, $362 \mathrm{pp}$.

Pethiyagoda R. 2006. Conservation of Sri Lankan fresh water fishes. In: The fauna of Sri Lanka: Bambaradeniya C. (Ed), World Conservation Union, 103-112.

Roberts TR, Vidthayanon C. 1991. Systematic revision of the Asian catfish Family Pangasiidae, with biological observations and descriptions of three new species. Journal of the Academy of Natural Sciences of Philadelphia, 143:97-144.

Silva P, Kurukulasuriya M. 2010. Invasive alien fauna in Sri Lanka - Introduction, spread, impacts and management. In: Invasive Alien Species in Sri Lanka - Strengthening Capacity to Control Their Introduction and Spread (Eds: Marambe B, Silva P, Wijesundara S. and Atapattu N.), Biodiversity Secretariat of the Ministry of Environment, Sri Lanka, 39-61.

Singh AK, Lakra WS. 2012. Culture of Pangasianodon hypothalamus into India: Impacts and present Scenario. Pakistan Journal of Biological Sciences, 15: 19-26.

Vidthayanon C, Hogan Z. 2013. Pangasianodon hypophthalmus. The IUCN Red List of Threatened Species. Version 2014.3. www.iucnredlist.org (accessed on May 16 2015).

Vidthayanon C, Karnasuta J, Nabhitabhata J. 1997. Diversity of freshwater fishes in Thailand. Office of Environmental Policy and Planning, Bangkok. 102 pp. 